\title{
MARGINAL LEAKAGE OF POLYACID-MODIFIED COMPOSITE RESIN RESTORATIONS IN PRIMARY MOLARS. AN IN VITRO STUDY
}

\author{
INFILTRAÇÃO MARGINAL EM RESTAURAÇÕES DE RESINAS COMPOSTAS \\ MODIFICADAS POR POLIÁCIDOS, EM MOLARES DECÍDUOS. ESTUDO IN VITRO
}

\section{Cleide Cristina R. MARTINHON ${ }^{1}$, Ricardo Sousa VIEIRA ${ }^{2}$}

1- PhD, Professor of Cariology, Marília University - SP.

2- PhD, Assistant Professor of Department of Pediatric Dentistry, Federal University of Santa Catarina, UFSC.

Corresponding address: Prof ${ }^{a}$. Dr ${ }^{\mathrm{a}}$. Cleide Cristina R. Martinhon - Rua dos Bancários 276 - CEP 17516-620, Marília, São Paulo, Brazil Fone: 14-3433-4770. E-mail: pityccrm@terra.com.br

Received: March 15, 2004 - Modification: September 09, 2004 - Accepted: February 15, 2005

\begin{abstract}
T

he purpose of this in vitro study was to compare the marginal leakage in primary molars restored with 2 polyacid-modified composite resins (Dyract AP - Dentsply and F2000 - 3M) and a composite resin (Filtek Z250 - 3M) as control. First and second primary molars were used for preparation of cavities on the proximal surfaces, with extension of the gingival margin to the cementoenamel junction. Restorations were accomplished after total etching and application of the respective adhesive system, and were divided into groups according to the restorative system and the number of adhesive layers used. The teeth were stored in distilled water for 7 days, followed by thermocycling with 500 cycles at $5^{\circ} \mathrm{C}-55^{\circ} \mathrm{C}$, with one minute in each bath. Thereafter, teeth were prepared for immersion in $0.5 \%$ methylene blue solution for four hours. The teeth were sectioned in mesiodistal direction for assessment of dye penetration. According to the results of the Kruskal-Wallis test, the three restorative materials employed did not completely avoid marginal leakage at the gingival margin of primary molars. The marginal leakage of PMCR F2000 (4.06 and 3.95) displayed to be higher than the marginal leakage observed for the materials Dyract AP (2.7 and 2.55) and Filtek Z250 (2.25 and 2.43). The number of adhesive layers did not influence the degree of leakage of the three materials

Uniterms: Marginal leakage; Composite resins; Primary teeth.
\end{abstract}

\begin{abstract}
RESUMO
estudo in vitro avaliou a infiltração marginal em molares decíduos restaurados com três materiais resinosos: as resinas compostas modificadas por poliácidos (Dyract AP - Dentsply e F2000 - 3M) e uma resina composta (Filtek Z 250) como grupo controle. Foram utilizados primeiros e segundos molares decíduos hígidos e as cavidades foram confeccionadas nas faces proximais, estendendo-se até a junção amelo-cementária. As restaurações foram realizadas após o condicionamento ácido total e a aplicação dos sistemas adesivos divididas em grupos de acordo com o sistema restaurador e o número de camadas dos respectivos agentes adesivos, ou seja, dois grupos para cada material restaurador. Os dentes foram armazenados em água destilada durante 7 dias, em seguida a ciclagem térmica com 500 ciclos $\left(5^{\circ} \mathrm{C}\right.$ e $\left.55^{\circ} \mathrm{C}\right)$, com um minuto em cada banho. Em sequiência os dentes foram selados para a imersão na solução de azul de metileno a $0,5 \%, \mathrm{pH} 7,2$, por 4 horas. A seguir, os dentes foram submetidos a cortes no sentido mésio-distal para a avaliação do grau de penetração do corante. De acordo com os resultados após a análise estatística, os três materiais testados não impediram completamente a infiltração marginal na região cervical dos molares decíduos. Com relação à infiltração marginal a RCMP F2000 (4,06 e 3,95) apresentou os maiores graus de infiltração marginal do que os outros materiais Dyract $\operatorname{AP}(2,71$ e 2,55) e Filtek Z250 (2,27 e 2,43). O número de camadas dos adesivos não influiu nos graus de infiltração dos três materiais estudados.

Unitermos: Infiltração marginal: Resinas compostas; Dente decíduo.
\end{abstract}




\section{INTRODUCTION}

One of the factors that determine the long-term success of composite resin restorations is the presence or absence of gaps at the tooth/restoration interface due to the polymerization shrinkage inherent to composite resins. Clinicians are concerned with the poor adaptation of materials to the tooth structure when placing a posterior restoration. A material's ability to seal a cavity preparation can be influenced by its composition, plastic deformation, flow, coefficient of thermal expansion, modulus of elasticity and the mechanical stresses caused by cavity preparation shape $^{15}$. Studies that investigate microleakage have shown that selection and handling of materials are the most significant factors influencing marginal adaptation and subsequent microleakage ${ }^{11}$.

The polyacid-modified composite resins, in turn, have shown better physical properties than the resin-modified glass ionomer cements, excellent esthetic qualities and good marginal sealing. They combine the benefits of glass ionomer cements such as adhesion to the dental structures, fluoride release, biocompatibility, besides the easy manipulation ${ }^{12}$. These materials were developed by the dental industry without taking into account the characteristics of primary teeth, even though most children are affected by caries during the first childhood. In restorations in primary teeth, this is even worse: they present smaller enamel and dentin thickness, and a contact surface instead of a contact point, which increases the proximal box of the restoration, making it more fragile to fracture and marginal microleakage. Since marginal leakage is a challenge in clinical practice, especially in Pediatric Dentistry, the present in vitro study was conducted.

The purpose of this study was to conduct an in vitro comparison of the degree of marginal leakage of two polyacidmodified composite resins (RCMP), Dyract AP (Dentsply) and F2000 (3M), and a hybrid composite resin, Filtek Z 250 (3M).

\section{MATERIALS AND METHODS}

The present study employed 42 primary molars supplied by the Tooth Bank of the Federal University of Santa Catarina.

The presence of caries, spots or cracks was investigated with magnifying lenses before preparation of the cavities with carbide burs \#330 (KG Sorensen) at high-speed.

Two Class II cavities were prepared in 42 primary molars, one on the mesial aspect and the other on the distal aspect; preparation was made up to the cementoenamel junction and restored according to Figure 1.

Group I (14 aspects) - restored with RCMP F2000 (3M), following the manufacturer's instructions for application of the bonding system (Single Bond - 3M).

Group II (14 aspects) - restored with RCMP F2000 (3M), using five layers of the adhesive system (Single Bond $3 \mathrm{M})^{9,12}$.
Group III (14 aspects) - restored with RCMP Dyract (Dentsply), following the manufacturer's instructions for application of the bonding system (Prime-Bond 2.1).

Group IV (14 aspects) - restored with RCMP Dyract Dentsply), using five layers of the adhesive system on each aspect (Prime-Bond 2.1) $)^{9,12}$.

Group V (14 aspects) - restored with RC Filtek Z250 (3M), following the manufacturer's instructions for application of the bonding system (Single Bond - 3M).

Group VI (14 aspects) restored with RC Filtek Z 250 (3M), with five layers of the bonding system (Single Bond - 3M) 9,12 .

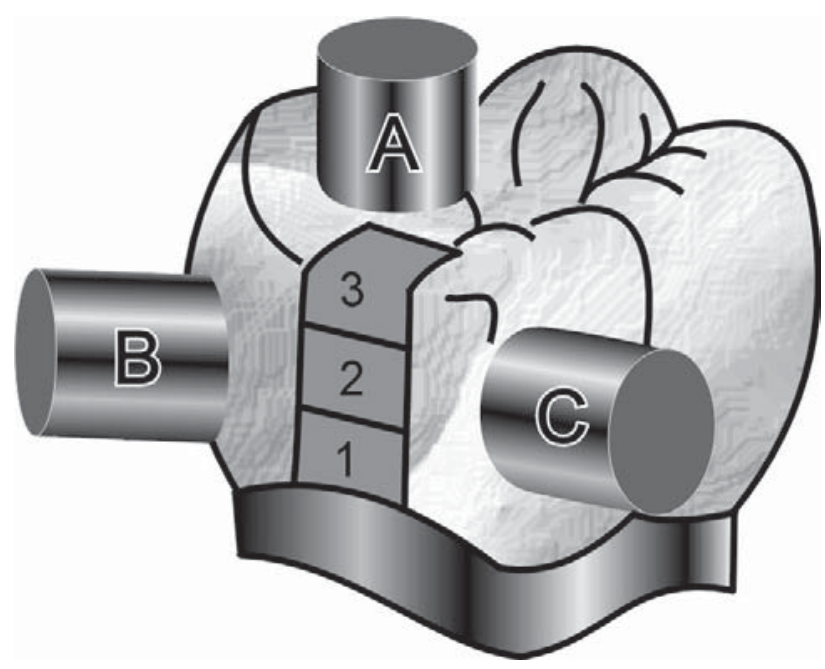

FIGURE 1- Schematic drawing of the material insertion and light curing

After finishing, restorations were stored in distilled water for one week. Thereafter, the teeth were washed, dried and coated with two layers of nail enamel, except for the restorations and a 1-mm margin around them. The teeth were then submitted to thermocycling, with 500 cycles at $5^{\circ} \mathrm{C}$ $55^{\circ} \mathrm{C}$, with one minute in each bath. Afterwards, the teeth were once again washed and dried and another layer of nail enamel was applied, and then the teeth were immersed in $0.5 \%$ methylene blue solution $(\mathrm{pH}$ 7.2) for four hours, followed by washing in tap water for removal of excess dye ${ }^{1}$.

After application of the disclosing agent, the teeth were cut in slices so that scores could be assigned according to the leakage at the gingival margin: Zero - no leakage at the tooth/ restoration interface; 01 - leakage in enamel or up to $1 / 3$ of the dentin; 02 - leakage until the middle of the dentin gingival wall; 03 - leakage in the entire dentin gingival wall; 04 - leakage in the entire gingival wall, reaching the axial wall and pulp ${ }^{2,4,10}$ (Figure 2).

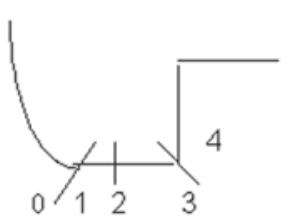

FIGURE 2- Schematic drawing of $t$ 
After recording of the readings, the median was calculated and the results were submitted to statistical analysis by means of the Kruskal-Wallis test, at a significance level of $0.05 \%$.

\section{RESULTS}

According to the Mean Rank of each group (Tables 1 and 2), the differences were not significant between the number of layers of bonding material employed, thus with no difference between the application of two or five layers. Individual comparison of the groups revealed that Groups 3,6 , and 5 are similar to each other and present the best results as to the marginal leakage compared to Groups 1 and 2 (Table 2 and Figure 3)

The materials Dyract and Filtek Z250 were similar to each other and displayed the lowest degrees of marginal microleakage, regardless of the number of adhesive layers. On the other hand, the F2000 material presented a high degree of marginal leakage, with no influence from the number of layers of the adhesive system.

\section{DISCUSSION}

The number of layers of the adhesive system did not significantly influence the degree of leakage, i.e. within each material. The presence or not of several layers of adhesive also did not reduce the leakage on the several study groups, except for Group 5, for which the median leakage scores was zero (Table 1).

However, Kemp-Scholte and Davidson ${ }^{9}$ (1990) demonstrated that the utilization of several layers of adhesive or a low-viscosity resin did not increase the bond strength to dentin, and that materials with a good sealing ability did

TABLE 1- Median and Mean Rank of the leakage scores obtained by the three examiners for the six experimental groups

\begin{tabular}{lcccccc} 
& Group 1 & Group 2 & Group 3 & Group 4 & Group 5 & Group 6 \\
Med & 3 & 3 & 1 & 1 & 0 & 1 \\
Mean Rank & 4.06 & 3.95 & 2.71 & 2.55 & 2.27 & 2.43 \\
\hline
\end{tabular}

Med: median

TABLE 2- Results of the Kruskal-Wallis test with the respective individual comparisons between the six experimental groups

\begin{tabular}{lll}
$\begin{array}{l}\text { Test result } \\
\mathbf{T}=\mathbf{1 5 . 4 7}\end{array}$ & $\begin{array}{c}\text { p value } \\
\mathbf{0 . 0 0 8 5}\end{array}$ & $\begin{array}{c}\text { significance } \\
\star \star\end{array}$ \\
\hline $\begin{array}{l}\text { Individual comparisons } \\
\text { Pmed }\end{array}$ & $\mathrm{p}<0.05$ \\
Group 1 & 4.06 \\
Group 2 & 3.95 \\
Group 3 & 2.71 \\
Group 4 & 2.55 \\
Group 6 & 2.43 \\
Group 5 & 2.27 & \\
\hline
\end{tabular}

** highly significant

P. med Mean Rank

note: vertical bars indicate statistical significance.
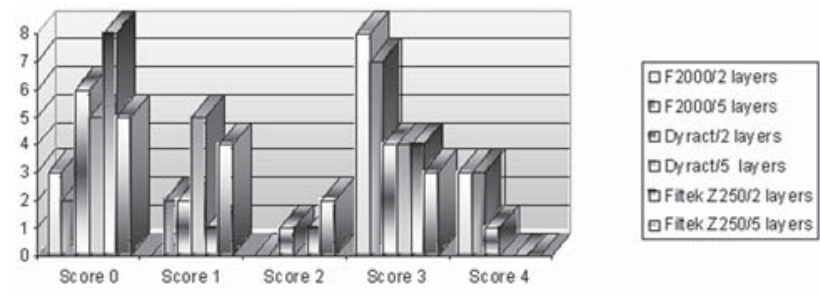

FIGURE 3- Graphic illustration of the sample distribution according to the levels of marginal leakage for each material employed not necessarily have high bond strengths and also did not hinder marginal leakage ${ }^{13}$. According to Prati and Nucci ${ }^{14}$ (1989), marginal adaptation may not be related to the bond strength to dentin, but rather to the flexibility of the restorative system, and thus the solution of the problem of marginal leakage would be based on the increase of the flexibility of the material ${ }^{16}$. Kemp-Scholte and Davidson ${ }^{9}$ (1990) concluded that the application of several adhesive layers considerably reduced the polymerization shrinkage of composite resins. In the present study, despite calculation of the results based on their median, the difference between the values achieved for the materials and number of adhesive layers was not significant, in disagreement with the study of Deliperi, et al. ${ }^{7}$ (2003), on which the application of several layers of the adhesive system contributed to a reduction in microleakage compared to application of a single adhesive layer.

Crim $^{6}$ (1988), Kemp-Scholte and Davidson ${ }^{9}$ (1990) advocate that utilization of several adhesive layers or of a low-viscosity resin can provide better marginal adaptation. This better fit could be assigned to a better resin/adhesive flow on the cavity walls, leading to the achievement of higher bond strength. Thus, it was concluded that the application of several adhesive layers considerably reduces the polymerization shrinkage of composite resins. However, the critical point of these materials is the microleakage, which is responsible for development of recurrent caries, marginal staining and postoperative sensitivity, which are caused by marginal leakage of oral fluids, bacteria, molecules or ions at the interface between teeth and restorative materials. According to Cortes, et al. ${ }^{5}$ (1988), the marginal leakage in 
Dyract AP restorations is highly reduced when total etching is performed. The levels of marginal leakage found by Fritscher, et al. ${ }^{8}$ (2000) for the F2000 were classified as severe in $52 \%$ of the sample. This present in vitro study revealed that the end of margins on the cementoenamel junction leaves little or no enamel margin for etching and bonding of the material, facilitating dye leakage. The present results are supported by Civelek et al. ${ }^{3}$ (2003), who reported an increase in microleakage on the margins on the cementoenamel junction.

\section{CONCLUSION}

Considering the behavior of materials evaluated as to the marginal leakage, it can be implied that all materials studied displayed leakage, regardless of the restorative material and the number of layers of bonding agent employed. A doubt remains as to the comparison of materials developed for permanent teeth and their behavior when employed in the primary dentition.

\section{REFERENCES}

1- Bussadori SK. Microleakage in primary teeth in relation to materials and acid etching. São Paulo; 1997. [Dissertation of Master's degree São Paulo University]

2- Cavalcanti AL, Chelotti A. Evaluation "in vitro" of the microleakage in cavities class ii of deciduous molars, restored with composite resin self-curing and light-curing. [online] [mentioned in May,23 2000] < Available in World Wide Web:http:// www.odontologia.com.br/artigos/avaliacao-microinfiltracaocavidades.html >

3- Civelek A, Ersoy M, L'Hotelier E, Soyman M, Say EC. Polymerization shrinkage and microleakage in class ii cavities of various resin composites. Oper Dent. 2003;28(5):635-41.

4- Coelho LMS. Evaluation of the degree of marginal leakage of restorations class II, type "slot", in the enamel-cement junction, in deciduous molars, restored with glass ionomer cement light-curing and resin composite: an "in vitro"study. Florianópolis; 1999. [Dissertation of Master's degree - Federal University of Santa Catarina].

5- Cortes $\mathrm{O}$ et al. Marginal microleakage around enamel and cementum surfaces of two compomers. J Clin Ped Dent. 1998;22(4):307-9.

6- Crim GA. Effect of composite resin on the microleakage of scotchbond and gluma. Am J Dent. 1988;1(5):215-6.

7- Deliperi S, Bardwell D M, Papathanasiou A, Perry R. Microleakage of resin-based liner materials and condensable composites using filled and unfilled adhesives. Am J Dent. 2003;16(5):351-5.

8- Fritscher A M G, Araujo D F, Conceição E E, Pacheco J F M. Evaluation of the marginal leakage of glass ionomer cement in enamel and dentin of primary teeth. J Bras Odontoped Odontol Bebê. 2000; $3(12): 130-8$.

9- Kemp-Scholte CM, Davidson CL. Complete marginal seal of class $\mathrm{v}$ resin composite restorations effected by increased flexibility. J Dent Res. 1990;69(6):1240-3.
10- Lutz F, Imfeld T, Barbakow F, Iselin W. Optimizing the marginal adaptation of MOD composite restorations. In: Vanherle G., Smith D C. Posterior composite resin dental restorative materials. St Paul: 3M; 1985. p.405-20.

11- Magnum FI, Berry EA, DeSchepper E, Rieger EMR. Microleakage of incremental versus compression matrix bulk filling of cervical resin composite restorations. Gen Dentistry. 1994;42(4):304-8.

12- Morabito A, Defabians P. The marginal seal of various restorative materials in primary molars. J Clin Ped Dent. 1997;22(1):51-4.

13- Peris AR, Duarte SJR., Andrade MF. Evaluation of marginal microleakage in class ii cavities: effect of microhybrid, flowable and compactable resins. Quintessence Int. 2003;34(2):93-8.

14- Prati C, Nucci C. Marginal gap, microleakage and shear bond strength of adhesive restorative systems. J Dent Res. 1989;68:1036.

15- Schwartz RS, Summit JB, Robbins JW. Fundamentals of operative dentistry: a contemporary approach. Chicago Quintessence Publishing;1996. p.141-86.

16- Van Meerbeek B, Perdigão J, Lambrechts P, Vanherle G. The clinical performance of adhesives. J Dent. 1998;26(1):1-20. 